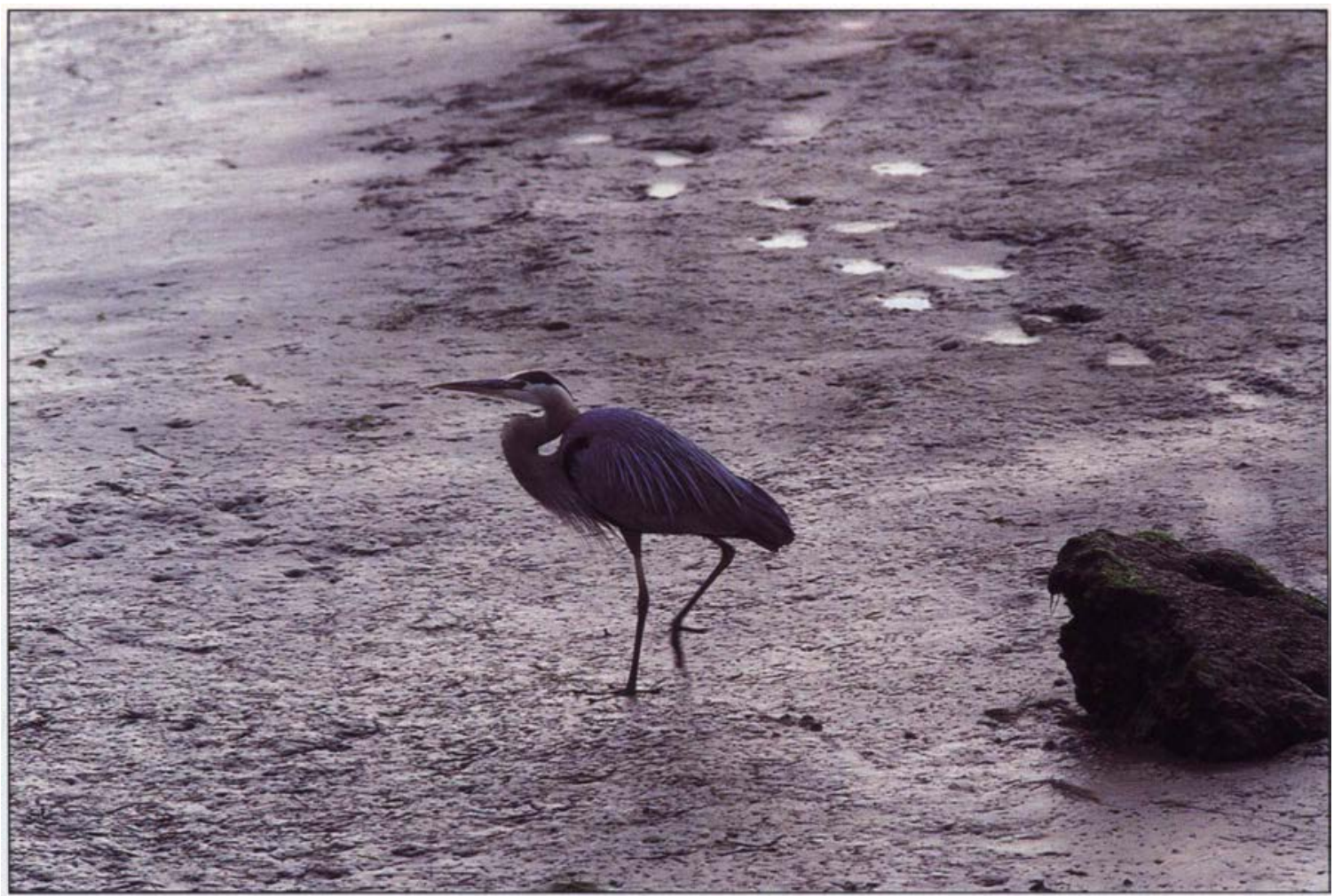

A great blue heron wanders the mudflats of a coastal harbor. Voluntary programs, as well as renewed legislative and regulatory efforts, are intended to address water quality concerns and their potential impact on ecosystem health at the interface of land and sea.

\title{
Polluted runoff impairs coastal water quality
}

$\mathrm{E}$ nvironmental and public health concerns have spurred a renewed emphasis on improving coastal water quality in California. Five of the 34 coastal bills introduced in the state Legislature this year directly address water quality issues.

According to a report on ocean resources issued by the state Resources Agency, nonpointsource (NPS) pollution is the state's most significant source of water pollution, degrading estuaries, bays and nearshore waters (Resources Agency 1997). State and federal clean-water regulations have been more successful in controlling point sources of pollution, such as industrial facilities and sewage treatment plants, than nonpoint sources. Voluntary programs to reduce NPS pollution are being implemented in a growing number of watersheds.

NPS pollution occurs when rainfall, snowmelt or irrigation water picks up pollutants as it runs over the land or percolates through the ground, then carries the pollutants into rivers, lakes, coastal waters or groundwater. Urban runoff, agriculture, forestry, grazing, septic systems, recreational boating, construction, physical changes to stream channels and degradation of wetlands are all potential contributors to NPS pollution. Careless or uninformed household use of water, pesticides and chemicals also adds to the problem.

These diverse and widely dispersed sources make it difficult to monitor and control NPS pollution. It is a big problem that results from a little bit of pollution coming from a lot of different sources, says Holly Price, director of the Water Quality Protection Program for the Monterey Bay National Marine Sanctuary.

"There is some shared responsibility among all of the inhabitants of a watershed," Price says. For this reason, public education and outreach are essential components of any strategy to reduce NPS pollution (see page 12).

The most common NPS pollutants are sediment and nutrients, according to the U.S. Environmental Protection Agency (EPA). These pollutants wash into water bodies from agricultural land, urban areas, construction sites, timber operations and other areas of disturbance. Other common NPS pollutants include pesticides, pathogens (bacteria and viruses), salts, oil, toxic chemicals and heavy metals.

Under the Clean Water Act, the EPA compiles a National Water Quality Inventory

continued on p. 13 
continued from $p .11$

every 2 years based on state surveys. Due to limited resources, the surveys are not comprehensive and provide only a general characterization of water quality. Nevertheless, the leading pollutants and their sources are identified for a small subset of the waters that are surveyed. According to the most recent surveys for California, the leading sources of pollution in the state's coastal waters are urban runoff and storm sewers, followed by municipal sewage treatment plants, agriculture, resource extraction, hydrologic and habitat modifications and industrial discharges (SWRCB 1996).

Urban runoff carries many types of pollutants, including oil, coolants, heavy metals, garden fertilizers, pesticides, pet waste and litter. Most urban runoff enters storm drains and flows untreated into rivers, bays and coastal waters. Bacteria and viruses in urban runoff have been associated with public health risks. Human fecal contamination can enter storm sewers from leaking septic tanks and sewer lines and from sewer overflows during heavy rainstorms. A recent survey of swimmers in Santa Monica Bay found that swimming near storm drain outlets during the dry season significantly increased the risk of becoming ill with symptoms such as fever, chills, gastroenteritis, or respiratory problems (SMBRP 1996).

The state surveys indicate that agriculture is a major contributor to pollution of estuaries and a moderate contributor to pollution of bays and harbors; it is also the leading source of pollution in California's rivers, streams and freshwater wetlands. Agricultural pollutants include sediments, nutrients (particularly nitrogen and phosphorus), animal wastes, pesticides and salts. In addition, agricultural activities have contributed to the loss of wetlands and riparian areas, which function as natural filters for sediments and associated pollutants.

Sediments from soil erosion can cause many problems, reducing the amount of sunlight that reaches aquatic plants, smothering bottomdwelling organisms, interfering with filter feeding, burying fish spawning grounds and filling in harbors. Sediments also carry other pollutants, such as persistent pesticides, which may be adsorbed to soil particles.

Many growers have already adopted practices that reduce NPS pollution, according to Price. These include conservation tillage; creating sediment basins to catch runoff and allow sediments to settle out; using buffer strips of vegetation around fields to slow and filter run- off; planting cover crops; and carefully monitoring pesticide and fertilizer use.

"Expanding the use of relatively simple practices can have a great impact, like cover cropping or adding compost to the soil to increase water retention and soil fertility," Price says.

The Resources Agency report noted that California does not have a system to comprehensively monitor water quality in watersheds and coastal areas. Existing monitoring programs are fragmentary and incomplete. Better coordination and standardization of monitoring programs would help to identify major NPS pollution problems and to evaluate the effectiveness of efforts to reduce it.

"Nonpoint-source pollution is the biggest source of pollution of the state's waters, yet there is no current formal program to deal with it," says Linda Sheehan of the Center for Marine Conservation.

Monitoring is one of the issues being addressed by the state Legislature. The Coastal Water Quality Monitoring bill (A.B. 1429) would develop a uniform system for monitoring storm water emissions and require the State Water Resources Control Board to recommend and implement a coastal water quality monitoring program. Another bill (A.B. 411) calls for the establishment of statewide coastal water quality criteria and would require monitoring and posting of recreational areas. The Nonpoint Pollution Control bill (S.B. 499) would require the state to develop and implement a program to control NPS pollution in the state's coastal waters.

"There is increasing recognition of the value of clean water to the state's economy," Sheehan says. "Coastal tourism alone puts nearly $\$ 10$ billion into the economy every year, but people won't come if they can't swim in the water."

\footnotetext{
$\overline{\text { References }}$

Resources Agency of California. 1997. California's Ocean Resources: An Agenda for the Future. Sacramento: State Printing Office. $332 \mathrm{p}$.

[SMBRP] Santa Monica Bay Restoration Project. 1996. An epidemiological study of possible adverse health effects of swimming in Santa Monica Bay. Final report 7 May 96. Monterey Park (CA): SMBRP. 211 p.

[SWRCB] State Water Resources Control Board. 1996. California 305(b) Report on Water Quality. Sacramento: SWRCB. $121 \mathrm{p}$.
}

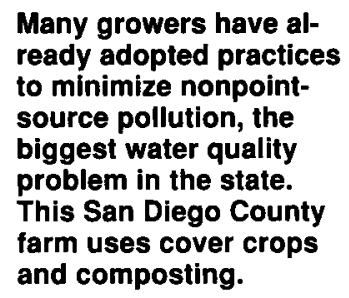

Many growers have already adopted practices source pollution, the biggest water quality problem in the state. This San Diego County and composting. 